\title{
CONSIDERAȚII PRIVIND DESIGNUL ACT,IUNILOR DE RIPOSTĂ ANTIAERIANĂ ÎN SPAȚIUL AERIAN ACTUAL
}

\author{
CONSIDERATIONS ON THE DESIGN OF THE AIR DEFENCE RESPONSE \\ IN THE CURRENT AIRSPACE
}

\author{
Col.conf.univ.dr. Daniel ROMAN*
}

\begin{abstract}
Dezvoltarea tehnologică fără precedent în domeniul armelor și munițiilor întrebuințate în spațiul aerian, la înălțimi mici și foarte mici, reprezintă una dintre provocările majore la adresa sistemelor clasice de ripostă antiaeriană. Pentru aceasta, specialiștii militari din armatele moderne acordă o atenție deosebită noilor posibilități de amenințare pe calea aerului și caută soluții pentru menținerea unei situații de echilibru în sfera securității spațiului aerian. În acest sens, sunt identificate o serie de transformări ale sistemelor de rachete antiaeriene VSHORAD, SHORAD. Soluțiile tehnice și tactice se referă, în principal, la creșterea posibilităților sistemelor de arme și muniții care pot fi utilizate la realizarea algoritmului specific de luptă cu inamicul aerian prin aplicarea anumitor metode specifice, TEWA. În acest demers științific, am evidențiat posibilitățile de acțiune pe calea aerului la înălțimi mici și foarte mici, ca punct de plecare în devenirea actuală a sistemelor de luptă antiaeriene, prin care, aplicându-se arta operativă, poate fi compensat temporar decalajul tehnologic existent între amenințarea aeriană și riposta antiaeriană.
\end{abstract}

The unprecedented technological development in the field of weapons and ammunition used in the airspace, at low and very low altitudes, is one of the major challenges that the traditional air defense systems have to face. To this end, the military specialists of the modern armies pay special attention to the new types of air threats and seek solutions to maintain a balanced situation in the field of airspace security. In this regard, a number of transformations of the VSHORAD, SHORAD air defense missile systems are identified. The technical and tactical solutions mainly refer to increasing the capabilities of the weapons and ammunition systems, which can be used in achieving the specific algorithm of countering an air threat by applying certain specific methods, TEWA (Threat Evaluation and Weapons Allocation). This scientific approach highlights the possibilities of taking short and very short range air action as a starting point in the current development of the air defense systems, which by applying the operational art can temporarily compensate for the technological gap between the air threats and the air defense response.

Cuvinte-cheie: amenințare aeriană; VSHORAD; SHORAD; TEWA; artă operativă.

Keywords: air threat; VSHORAD; SHORAD; TEWA; operational art.

\section{Noul context de luptă în spațiul aerian}

Nevoia de extensie a câmpului de luptă terestru a dus în mod direct la identificarea de soluții tehnologice în spațiul aerian apropiat, respectiv la dezvoltarea mijloacelor de acțiune pe calea aerului la înălțimi mici și foarte mici. Acest fapt este o realitate a câmpului de luptă modern, în care tot mai multe armate moderne folosesc sintagme, cum ar fi „,binom tanc - elicopter”. În acest context, putem vorbi de o creștere a densităţii utilizatorilor în spațiul aerian, în special la înălțimi mici și foarte mici. În ansamblul economiei de forțe și mijloace ale unui ipotetic adversar, întrebuinţate într-un

\footnotetext{
*Universitatea Națională de Apărare „Carol I” e-mail:danutroman2@yahoo.com
}

conflict militar, putem vorbi despre existența mai multor tendințe de acțiune în spațiul aerian, pe întreg spectrul de înălțimi. Acest fapt este posibil încă de la declanșarea agresiunii prin surprindere, fără a recurge la măsuri anterioare de mobilizare și de constituire a grupării întrunite de forțe și mijloace.

În progresia unei operații ofensive, pentru realizarea superiorității aeriene, este de așteptat întrebuințarea, în cadrul primei lovituri aeriene, a mijloacelor de neutralizare a apărării antiaeriene și de creare de breșe pentru pătrunderea în adâncimea tactică a obiectivului, fapt susținut de acțiuni de bombardament, de la înălțimi medii și mari. Pentru menținerea succesului în ofensivă, unul dintre obiectivele urmărite este realizarea, în primele 3 - 4 ore de la declanșarea agresiunii, a unei intensități maxime de lovire din aer, cu întrebuințarea 
mijloacelor de atac aerian cu suprafețe mici de reflexie, cu viteze de zbor mari, cu largi posibilități de manevră, sub protecția unui puternic bruiaj de radiolocație. În acest context, cel mai probabil vor fi întrebuințate culoarele de zbor pe direcțiile din care se execută atacul și pe căile de acces către obiectivele din adâncimea tactică, operativă și strategică. Astfel, este de așteptat folosirea pe scară largă a diferitelor tipuri de armament și muniţii, în principal a rachetelor care se ghidează pe fascicolul staţiilor de radiolocaţie, și nu în ultimul rând, folosirea dronelor (ca amenințări asimetrice în domeniul aerian), a senzorilor de observare și dirijarea focului pentru artileria grea cu rază lungă de acțiune și a rachetelor sol-sol.

\section{Amenințarea și riposta antiaeriană în spațiul aerian stratificat}

Din studiul conflictelor militare recente, în speță războiul din Nagorno-Karabah (toamna anului 2020), au rezultat noi dimensiuni ale confruntării, în sensul existenței acelor mutații tehnologice în zona întrebuințării mijloacelor aeriene clasice (avioane și elicoptere multirol). Din radiografia conflictului, reiese faptul că a fost introdusă în luptă o nouă generație de mijloace aeriene UAV (unmanned aerial vehicle). În concepția planificatorilor militari, în urma rezultatelor analizei pe acțiunile de luptă în spațiul aerian în războiul din Nagorno-Karabah, au fost identificate trei domenii de perspectivă, astfel: nevoia unui sistem integrat de apărare aeriană, ca o condiție critică în desfășurarea operațiilor; creșterea rolului războiului electronic, ca un aspect al confruntării, care trebuie accentuat în toate fazele operațiilor, precum și pregătirea factorului uman sau a decidentului în conducerea operațiilor ${ }^{1}$. Necesitatea existenței unui sistem integrat de apărare aeriană (IADS - Integrated Air Defense System) este o realitate a spațiului de luptă modern, vitală pentru contracararea amenințărilor aeriene, fapt ce solicită o nouă configurație de apărare antiaeriană, stratificată pe înălțimi și axată, în principal, pe lucrul integrat în rețea ${ }^{2}$. Lucrul într-o rețea integrată, ca modalitate de luptă, poate fi acea variantă prin care are loc întrebuințarea simultană a resurselor aeriene și antiaeriene, fapt ce ar permite o gestionare mult mai eficientă a multitudinii de provocări, de la avioane multirol la multitudinea de configurații tehnologice de UAV.

Varianta clasică de amenințare în spațiul aerian la înălțimi mici și foarte mici presupune străpungerea sistemului de apărare antiaeriană a teritoriului și lovirea obiectivelor din adâncimea tactică. Acest lucru este de aşteptat încă din primele ore ale unui conflict militar, fapt realizabil printr-o abordare manevrieră de modificare dinamică a dispozitivului de luptă și a procedeelor de acțiune. Cel mai probabil, aviația de cercetare strategică va executa cercetarea aeriană ziua și noaptea, cu avioane izolate, care zboară cu viteze cuprinse între $700 \mathrm{~km} / \mathrm{h} s ̧ i, 900 \mathrm{~km} / \mathrm{h}$ la înălţimi mari și stratosferice (10.000 m și $18.000 \mathrm{~m})$, cu schimbări frecvente de direcție, viteză, înălțime, și va recurge la folosirea intensă a bruiajului radioelectronic.

În funcție de relieful zonei de confruntare, asociat cu posibilitățile de navigație și de luptă ale aeronavelor, sunt identificate culoarele de apropiere de obiectiv prin executarea zborului la înălţimi mici și foarte mici $(20$ - $150 \mathrm{~m})$, pe diferite traiecte ale țintelor aeriene. Practicarea înălțimilor mici și foarte mici ale culoarelor de apropiere pentru lovirea obiectivelor limitează descoperirea și urmărirea continuă a țintelor aeriene, în raport cu posibilităţile maxime ale staţiilor de radiolocaţie, și, implicit, împiedică nimicirea aeronavelor ostile de către sistemul de ripostă antiaeriană.

Pentru dezvoltarea subiectului, ,ameninţare aeriană" în cadrul planificării acțiunilor militare, am identificat trei domenii distincte de abordare, astfel: compunerea de luptă, dispunerea în câmpul tactic a acestora și posibilitățile tehnico-tactice ale structurilor adversarului aerian. Datorită acestui fapt, în studiul realizării ripostei antiaeriene, am pus în relații patru direcții de analiză: obiectivul de apărat antiaerian, inamicul/adversarul aerian, structurile de rachete și artilerie antiaeriană și spațiul aerian, de responsabilitate. Conform acestei abordări, rezultă direcționarea studiului asupra spațiului aerian stratificat pe înălțimi și o evaluare în dinamică a posibilităților de identificare și de vizualizare a traiectoriilor aeronavelor, pe secvențe ale luptei, împreună cu estimarea aliniamentelor probabile de tragere ale aeronavelor. Războiul din Nagorno-Karabah 2020 este caracterizat și sub aspectul etapelor premergătoare de pregătire tehnologică a acestuia, fapt pentru care, încă din 2010, au avut loc o serie importantă de achiziții de armament și muniții cu un nivel tehnologic ridicat.

Conform unui raport al Institutului internaţional de cercetare a păcii din Stockholm (SIPRI), publicat în 2018, „Armenia a primit o cantitate mare de 
echipamente militare din Rusia, inclusiv două sisteme de rachete de apărare aeriană S-300PS/ SA-10C, 10 vehicule blindate Tigr, 400 MANPADS Igla-S/SA-24; 25 de unităţi de rachetă balistică Iskander; 6 BM-30 9A52 Smerch MLRS 300 mm Multiple Launch Rachete System, 200 Verba SA-25 și un număr nedezvăluit de rachete antitanc 9M133 Kornet/AT-14"3. Conform informării biroului de știri Middle East Eye, din Londra, ,deși armata armeană a vizat lovirea capitalei Azerbaidjanului, Baku, cu rachete balistice Iskander în ultimele zile ale ostilităților din noiembrie 2020 ”, , ,armata azeră a reușit neutralizarea pe traiectorie a rachetelor balistice Iskander, folosind sistemul de apărare antiaeriană „Barak-8” (sistem antiaerian achiziționat din Israel)"s. Din acest caz, observăm importanţa existenței unui sistem de apărare antiaeriană cu acțiune stratificată pe înălțimi. În funcție de configurația tehnică finală a sistemului de ripostă antiaeriană, complexul „Barak- 8 ” are capacitatea de a angaja simultan mai multe ținte aeriene, cum ar fi: rachete antinavă, avioane, drone UAV și rachete supersonice.

Pentru înțelegerea modului de funcționare a sistemelor de ripostă antiaeriană în concept integrat VSHORAD, SHORAD, am ales complexul folosit în războiul din Nagorno-Karabah „Barak-8”, ca punct de referință pentru descrierea noii realităţi în sfera securității spațiului aerian actual. Analiza de situație se bazează pe înţelegerea configurației

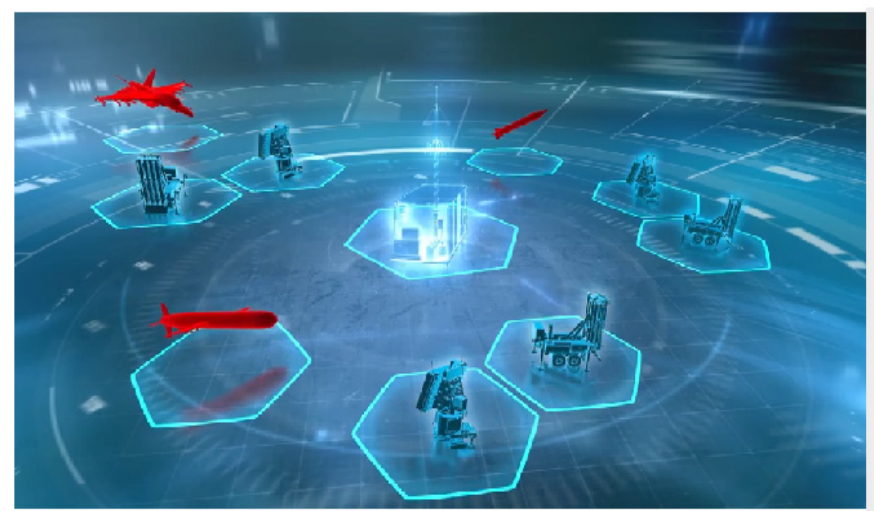

cu două trepte și cu o autonomie de $70 \mathrm{~km})$ și cea de a treia configurație „Barak ER” (interceptorul cu cea mai mare rază de acțiune, care are un motor rachetă cu două trepte și un booster suplimentar pentru o autonomie de $150 \mathrm{~km})^{6}$. Conceptul de ripostă antiaeriană „Barak” a fost dezvoltat într-o nouă abordare a securității spațiului aerian. Pentru îndeplinirea cerinței de bază, de a putea face față simultan mai multor tipuri de amenințări aeriene, a fost realizată integrarea mai multor tipuri de radare și lansatoare, care pot construi un răspuns optimizat împotriva avioanelor de luptă, elicopterelor, UAS-urilor, rachetelor de croazieră, rachetelor sol-aer și sol-sol. Posibilitatea de configurare flexibilă a sistemului de ripostă antiaeriană pe cele trei tipuri de rachete (MRAD, LRAD și Barak ER) se bazează pe comasarea funcțională a elementele comune ale subsistemelor: informaţional, de comandă și control, de foc și logistic. În configurație tehnică, realizată pe cele patru subsisteme acționale, este generat avantajul semnificativ de întreținere continuă, instruire și rezolvare a exercițiilor de antrenament de către diferiți utilizatori. Un astfel de concept inovativ a fost dezvoltat pe baza ,lucrului pe module funcționale", care oferă o flexibilitate ridicată sub aspect tehnologic integrativ, dar și operațional. În dezvoltarea ulterioară a noilor sisteme de armament pe același concept, rezultă o nouă posibilitate de angajare, mult mai performantă a sistemelor de apărare antiaeriană.

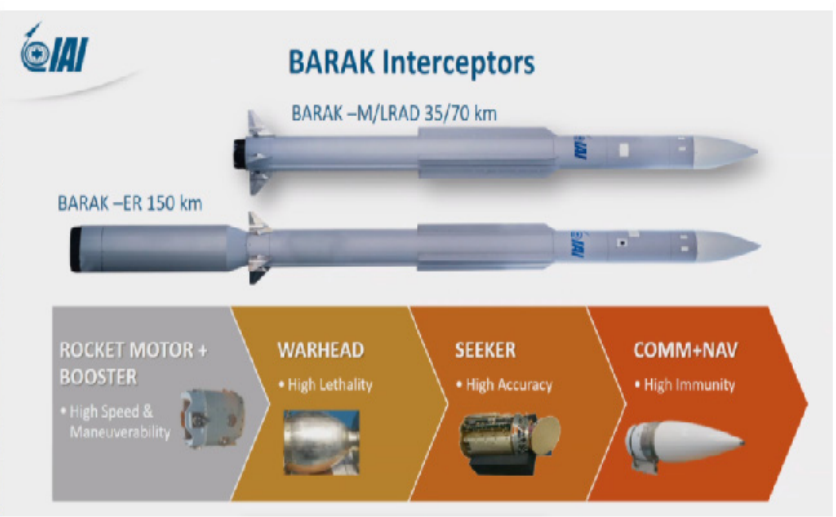

Figura 1 Reprezentarea conceptului modular integrat ,Barak-8” pentru contracararea amenințării aeriene în rază de acțiune progresivă $30-70-150 \mathrm{~km}^{7}$

extinse prin zonele de lansare progresivă a trei tipuri de interceptoare Barak, respectiv „Barak MRAD" (cu motor de rachetă cu o singură treaptă și cu o rază de acțiune de $35 \mathrm{~km}$ ), configuraţia intermediară „Barak LRAD” (cu motor de rachetă
Datorită complexității lucrului pentru realizarea unei riposte antiaeriene eficiente împotriva spectrului larg de amenințări în spațiul aerian, factorii de decizie trebuie să apere antiaerian atât o serie de obiective vitale din teritoriu, cât și 
trupele aflate în desfășurarea unei operații militare. Problema evaluării performanței unor astfel de sisteme antiaeriene în concept întrunit devine o problemă de mare importanță. Aspectul inovator al conceptului constă în realizarea centrului de management al luptei (BMC) BARAK, unde este realizată imaginea spațiului aerian prin date/ imagini, fuzionate cu senzori și coordonate de interceptare, care, analizate electronic, ajută decizia grupurilor operaționale de luptă să gestioneze angajarea adversarului aerian. Prin urmare, arhitectura deschisă și inovatoare a unui astfel de complex antiaerian, bazată pe software-ul lui „BARAK MX”, oferă o flexibilitate excepțională în funcționare și în proiectarea puterii de luptă la amenințările viitoare în spațiul aerian.

\section{Arta operativă pentru designul acțiunilor de luptă în spațiul aerian}

Noul context actual de securitate în spațiulaerian solicită elaborarea unor structuri noi de apărare aeriană integrată și stratificată, corespunzătoare complexului de amenințări pe calea aerului. Flexibilitatea operațională în acest caz poate fi una dintre soluțiile necesare pentru proiectarea modulară pe funcțiuni de luptă, într-un algoritm de ripostă antiaeriană secvenţial, astfel: cercetarea spațiului aerian, descoperirea și clasificarea țintelor aeriene, identificarea apartenenței aeronavei, combaterea și nimicirea țintelor aeriene ostile, evaluarea secvențe distincte, realizate de module specializate fiecărei operații antiaeriene, cum ar fi complexul de rachete antiaeriene de generație mai veche, S-75 M3 „VOLHOV”, sau de generație mai nouă, MIM-104 „PATRIOT”. A doua variantă se referă la integrarea într-un singur modul tehnologic/mașină de luptă a tuturor funcțiunilor prin care se realizează riposta antiaeriană, cum ar fi complexul de rachete antiaeriene SA-8 „Osa-AKM” sau complexul de artilerie antiaeriană „GEPARD”, respectiv 2K22 „TUNGUSKA".

Metoda ripostei antiaeriene în ambele variante tehnologice se bazează pe rezultatele aplicării artei operative în realizarea designului acțiunilor de luptă în spațiul aerian. $\mathrm{Cu}$ alte cuvinte, succesul apărării împotriva adversarului aerian constă în realizarea dispozitivului de luptă sau, altfel spus, este condiționat de modalitatea de combinare a patru variabile de sistem, respectiv: obiectivul de apărat antiaerian, inamicul/adversarul aerian, structurile de rachete şi artilerie antiaeriană și spaţiul aerian de responsabilitate. Arta operativă este aplicată în sfera securităţii spaţiului aerian pentru a stabili modalitățile și mijloacele necesare realizării apărării antiaeriene a obiectivelor, în condiții de eficacitate și în limitele unor riscuri acceptate. A2AD (Anti-access, Area Denial) nu este un concept absolut nou, iar ca rezultat direct al aplicării artei operative în zona Mării Negre, au apărut acțiuni concrete ale Federației Ruse pentru
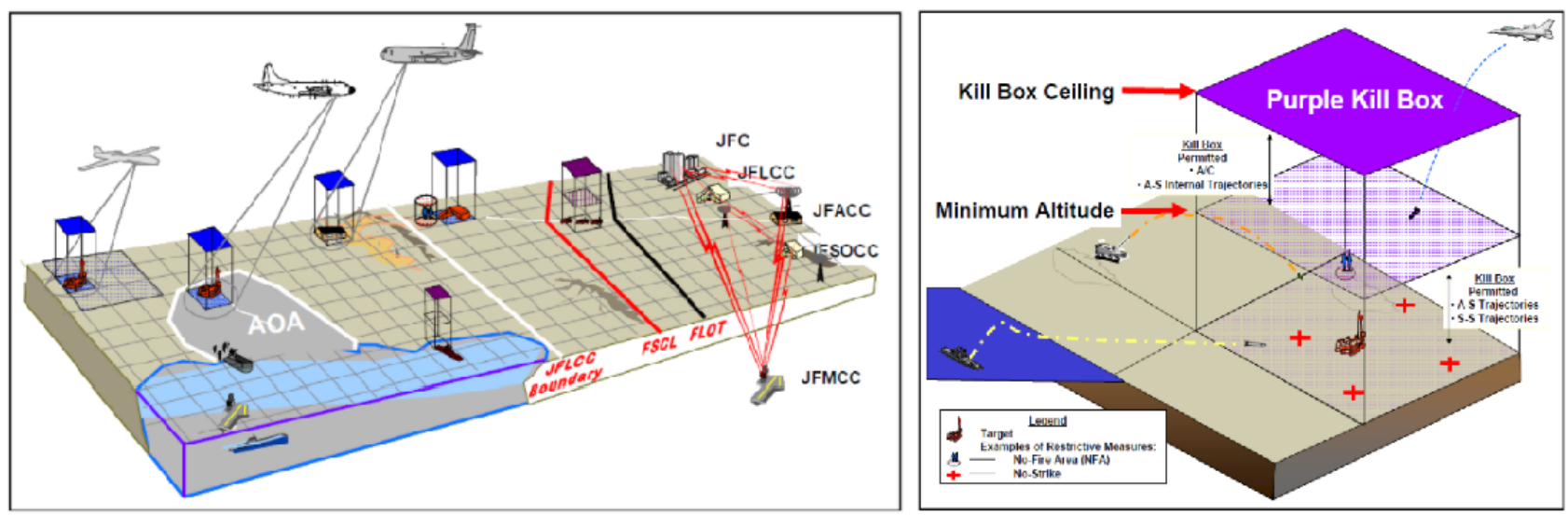

Figura 2 Reprezentare grafică a conceptului de realizare a unei zone „, Kill box ”, ${ }_{11}$

rezultatului tragerilor antiaeriene, încetarea sau reluarea algoritmului antiaerian.

O primă observație este aceea că, în plan tehnologic, există două tendințe de realizare a algoritmului de ripostă antiaeriană. Prima variantă se referă la proiectarea luptei cu adversarul aerian pe „reanimarea sistemelor de radare de avertizare timpurie şi instalarea de echipamente de război electronic modern", ca noi capabilități în Crimeea ${ }^{8}$. Combinarea mijloacelor de luptă în spațiul aerian implică o serie de proiecții și de analize integrate pentru identificarea celor mai eficiente variante de 
realizare a contracarării acțiunilor unui ipotetic adversar în zona de responsabilitate. Astfel, este de așteptat ca, în zona Mării Negre, ,„prin dislocarea acestor capabilităţi, împreună cu sistemele de rachete, Rusia să fie capabilă să creeze o reţea de apărare multistratificată, interconectată, ce poate ameninţa sau interzice prezenţa oricărei alte forţe în interiorul bulei A2AD"'.

Prin urmare, aplicarea artei operative, care promovează acțiunea întrunită, devine esențială pentru realizarea designului acțiunilor de luptă în spațiul aerian ${ }^{10}$. Urmărind conceptul A2AD, înțelegem proiectarea spațială şi coordonarea în timp a tuturor mijloacelor specializate care pot angaja un ipotetic adversar, pe o scară largă a ameninţărilor posibile într-o zonă de responsabilitate, cum ar fi Marea Neagră. În acest sens, apreciez faptul că, prin aplicarea artei operative, rezultă combinarea tacticilor, tehnicilor și procedurilor cu mai multe servicii și capabilități, care, în mod întrunit, asigură dezvoltarea, stabilirea și executarea așa-numitei zone ,kill box”, fapt ce ar permite angajarea rapidă a unei ținte.

Prin urmare, constatăm existența a două metode integratoare de realizare a ripostei antiaeriene: prima, conform conceptului modular integrat „Barak-8/BARAK MX”, și cea de a doua, conform conceptului de realizare a unei zone „,kill box" cu mai multe sisteme de arme. In varianta „BARAK MX” cu o configurare flexibilă a sistemului de ripostă antiaeriană pe cele trei tipuri de rachete (MRAD, LRAD și Barak ER), rezultă posibilitatea unei zone extinse, stratificată de ,kill box", pentru un anumit tip de amenințare, o situație care este realizată pentru un anumit tip de ripostă antiaeriană dedicată, de către o singură unitate de luptă (ca în Figura 1), progresiv, cu cele trei tipuri de rachete. În ambele variante, la care m-am referit, constatăm faptul că, în situațiile de apărare aeriană, respectiv de apărare antiaeriană, factorii de decizie fac o proiecție a luptei cu adversarul aerian în coordonate de asistență computerizată, în funcție de obiectivele din teritoriu, sau a trupelor aflate în operațiile militare ${ }^{12}$. Astfel, este construit un raport corespunzător de alocare a unităților de tragere antiaeriene disponibile pentru fiecare secvență de luptă, în timp real împotriva țintelor aeriene.

În literatura de specialitate, pregătirea informativă a mediului operațional asigură elaborarea deciziilor pentru realizarea dispozitivului de luptă și poziționarea sistemelor de arme în spațiul de luptă. Una dintre metodele folosite în acest scop constă în conectarea în rețea a sistemelor de evaluare a ameninţărilor și în alocarea adecvată a armelor pentru angajarea țintelor aeriene (TEWA - threat evaluation and weapon allocation systems). Problema evaluării performanței lucrului prin conectare în rețea a sistemelor de ripostă antiaeriană sau de angajare a adversarului aerian reprezintă una dintre provocările spaţiului de luptă contemporan. Un ipotetic adversar aerian va angaja obiective din teritoriul vizat prin schimbarea progresivă a tacticii de luptă pe înălțimi și cu viteze diferite, în funcție de configurația terenului și de posibilitățile de manevră, în scopul evitării focului antiaerian de la sol. Conceptul modular integrat, de ripostă antiaeriană ,BARAK MX”, ca în Figura 1, contribuie la înțelegerea nevoii de reproiectare a întregului sistem de ripostă antiaeriană. Una dintre soluțiile posibile în acest sens poate fi modelul de lucru în rețea a unităților de foc antiaerian și realizarea unui sistem centralizator de date privind situația aeriană, prin metoda TEWA, ca în Figura 3.

Valorificarea realizării unitare a unei rețele de lucru antiaerian, prin operaționalizarea metodei TEWA, așa după cum rezultă din Figura 3, poate o soluție de tranzit de la sistemele clasice de ripostă antiaeriană către acel sistem unic, autonom de rețea, asistat de computer. Acest fapt se bazează pe posibilitatea de proiectare și de realizare a mai multor noduri informaționale de rețea, în care este compusă progresiv imaginea aeriană comună, în modulul GUI (graphical user interface), care poate fi distribuită ulterior fiecăruia din cele șase sisteme de arme interconectate, ca în Figura 3. În funcție de înălțimea de zbor și de alți parametri ai țintelor aeriene, conform situației de amenințare şi de agresiune în spațiul aerian stratificat, rezultă o activare progresivă a senzorilor şi, implicit, o declanșare a procedurilor individuale pentru angajarea, combaterea și nimicirea țintelor aeriene din spațiul aerian comun. Conform capabilităţilor de luptă ale fiecărui sistem antiaerian în parte, acestea vor contribui la realizarea unui volum de foc antiaerian progresiv, minim necesar cu o economie de forțe pe unitatea de luptă și de timp. Acest lucru rezultă în special pentru situaţia unor obiective fixe de apărat antiaerian din zona de operații. În schimb, datorită mobilității acestora în câmpul tactic, pentru apărarea antiaeriană a trupelor aflate 


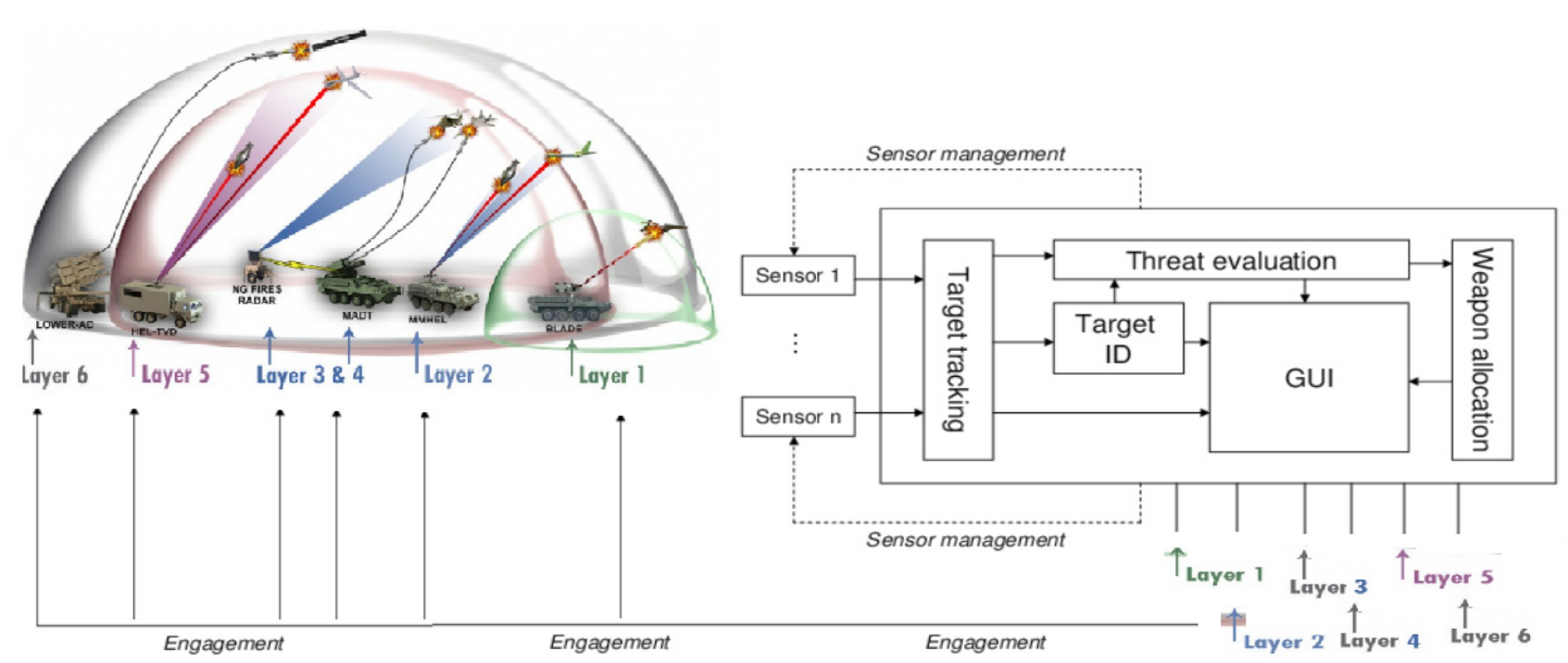

Figura 3 Variantă schematică pentru lucrul de rețea în realizarea ripostei antiaeriene în concept TEWA

în desfășurarea unei operații militare, vor scădea posibilităţile de apărare antiaeriană, corespunzător configurației terenului și dinamicii din progresia operațiilor militare.

Prin urmare, rezultă un compromis situaţional necesar în realizarea unei riposte antiaeriene eficiente împotriva unui adversar aerian, care poate acționa la diferite înălțimi, cu viteze diferite și cu schimbarea progresivă a tacticii de luptă $\breve{1}^{14}$. Cu alte cuvinte, realizarea unei riposte antiaeriene prin metoda TEWA cuprinde două ipoteze distincte de planificare în ceea ce privește combaterea și nimicirea țintelor aeriene. În formularea ipotezelor de planificare, mă voi referi la posibilitatea de alocare a armelor antiaeriene, ca o măsură reactivă la amenințarea aeriană. Acest fapt conduce la întrebarea la care trebuie să răspundă procesul de alocare a armelor pentru activarea celui mai potrivit sistem de arme, mai exact care este unitatea sau care sunt unitățile de tragere pentru o anumită țintă aeriană. Pentru această abordare, rezultă formularea primei ipoteze de planificare în care obiectivul de apărat antiaerian este static, fapt care presupune activarea tuturor unităților de tragere disponibile într-o singură etapă. $\mathrm{O}$ astfel de activare are implicații directe asupra condițiilor de economie a forțelor și de execuție a focului antiaerian restricționat.

În cea de a doua ipoteză, în care obiectivul de apărat antiaerian se află în dinamica operației (trupele aflate în desfășurarea unei operații militare), putem vorbi despre o alocare în dinamică a armelor, conform progresiei luptei, astfel încât fiecărei unități de tragere i se va permite un număr definit de etape discrete de luptă. $\mathrm{O}$ altă diviziune care poate fi făcută referitoare la resursa de foc antiaerian este cea în care alocarea armelor este bazată pe evoluția situației aeriene, în care țintele sunt distribuite pe activele antiaeriene avute la dispoziție în fiecare secvență a operației. În ambele ipoteze formulate, aplicarea conceptului TEWA presupune existența unei platforme unice de decizie, fapt care ar face vulnerabil întregul sistem de ripostă antiaeriană, dacă nodul informațional de distribuție a deciziilor de angajare a platformelor aeriene ostile, ar fi lovit și scos din luptă. Pentru evitarea scoaterii din luptă a ,centrului de greutate”, respectiv punctul de decizie al operaţiilor antiaeriene, s-a urmărit reproiectarea războiului centrat pe rețea. Acest lucru este posibil printr-o conectare progresivă a senzorilor, sistemelor de angajare și, într-un final, a factorilor de decizie, ca într-un întreg eficient la dinamica evoluției în spaţiul aerian.

\section{Concluzii}

În urma celor prezentate referitor la evoluția posibilă a lucrului antiaerian, ne putem aștepta la o nouă concepție privind designul luptei cu adversarul aerian. Astfel, poate avea loc o nouă elaborare a luptei, în baza dezvoltării funcționalității TEWA, ca un proces dinamic de luare a deciziilor care vizează exploatarea cu succes a resurselor tactice (de exemplu, senzori și arme) pe timpul desfăşurării activităţilor de comandă și control. Prelungirea duratei de viaţă în câmpul tactic a complexelor antiaeriene de generație mai veche poate fi 
realizată în două modalităţi. Prima modalitate se referă la păstrarea configurației inițiale a complexelor antiaeriene și angajarea lor în lupta $\mathrm{cu}$ adversarul aerian prin modificarea parametrilor dispozitivului de luptă, concomitent cu aplicarea tacticilor și manevrelor de protecție nemijlocită și de înșelare, pentru evitarea confruntării directe. A doua modalitate constă în identificarea unor upgrade-uri tehnologice prin introducerea în sistemul informațional a unui nod de recepție și prelucrare date, conectat în rețea, cu ajutorul căruia să poată fi realizată riposta antiaeriană distinct, pe etape de luptă în mai multe „kill boxuri”, ca în Figura 2.

Pentru înțelegerea noului context de luptă în spațiul aerian, ca în războiul din Nagorno-Karabah, din 2020, ca și pentru alte conflicte ipotetice, bazate pe tehnologia armelor moderne, este necesară o reașezare conceptuală a spațiului de luptă. Datorită evoluției tehnologice a platformelor aeriene cât și a modului de gestionare a resurselor pentru lovirea obiectivelor din teritoriul adversarului, una din problemele cu care se confruntă comandanții/ factorii de decizie este utilizarea optimă a resurselor de ripostă antiaeriană în situații complexe, în absenţa timpului de reacție.

Un alt aspect este dat de introducerea în luptă a unei noi generații de mijloace aeriene UAV (unmanned aerial vehicle), fapt ce a determinat o serie de mutații importante în ducerea războiului cu mijloace clasice de ripostă antiaeriană, fără a exclude acțiunile avioanelor multirol și ale elicopterelor. Aducerea în atenția specialiștilor, în sfera de securitate a spaţiului aerian, a metodei TEWA, de realizare a artei operative pentru elaborarea designului acțiunilor de luptă cu un ipotetic adversar aerian, constituie punctul de plecare în reconceptualizarea spaţiului de luptă modern. Tot în acest sens, merită o atenție deosebită elaborarea conceptului A2AD (Antiaccess, Area Denial), dezvoltat de Federaţia Rusă, prin „reanimarea sistemelor de radare de avertizare timpurie şi instalarea de echipamente de război electronic modern", ca noi capabilități, în noi coordonate de suprafață, respectiv în zona militarizată Crimeea.

Nevoia de tehnologizare a sistemelor de ripostă antiaeriană va determina proiectarea unei arhitecturi deschise și inovatoare, după modelul complexului antiaerian, cu platformă de bază pe software-ul lui „BARAK MX”, ca o variantă de referință ce oferă o flexibilitate excepțională în funcționarea și proiectarea puterii de luptă la amenințările viitoare din spațiul aerian. Prin urmare, prin aplicarea artei operative fundamentată TEWA, are loc o combinare a tacticilor, tehnicilor și procedurilor cu mai multe servicii și capabilităţi în mod întrunit, fapt ce poate asigura dezvoltarea, stabilirea și executarea zonei „kill box” ca un proces în trei etape: definirea amenințării, evaluarea progresivă a amenințărilor și, în final, programarea armelor și atribuirea acestora. În cele din urmă, recomand însușirea conceptului TEWA ca pe un instrument extrem de eficient în elaborarea deciziilor și realizarea unei economii de forțe și mijloace, dar mai ales de timp de reacție în situaţii critice.

\section{NOTE:}

1 https://www.airuniversity.af.edu/JIPA/Display/Article/ 2743721/the-second-nagorno-karabakh-war-takeaways-forsingapores-ground-based-air-defen/, accesat la 03.11.2021.

2 Daniel Roman, Riposta antiaeriană a forțelor terestre din perspectiva modelelor conceptuale de lucru colaborativ, Editura Universității Naționale de Apărare „Carol I”, Bucureşti, 2017, p. 116.

$3 \mathrm{https}: / /$ caspiannews.com/news-detail/armenia-threat ens-azerbaijan-with-use-of-ballistic-missiles-2020-9-28-45/, accesat la 09.11.2021.

$4 \mathrm{https}: / /$ www.middleeasteye.net/news/azerbaijan-arme nia-israel-russia-missile-fired-shot-down, accesat la 09.11.2021.

$5 \mathrm{https}: / /$ caspiannews.com/news-detail/armenia-usediskander-missiles-against-azerbaijan-in-karabakh-war-saysarmenian-expert-2021-9-23-0/, accesat la 09.11.2021.

$6 \mathrm{https}: / / w w w . d e f e s a n e t . c o m . b r / e n / i a i e / n o t i c i a / 36678 /$ IAI-s-Barak-Air-and-Missile-Defense-System-usesnetwork-centered-technology-to-create-a-hermetic-shield/, accesat la 12.11.2021.

7 https://defense-update.com/20210419_barak-er.html, accesat la 12.11. 2021.

8 Marius Şerbeszki, „Militarizarea Mării Negre”, Conferința Gândirea militară modernă, București, 2019, https://gmr.mapn.ro/app/webroot/fileslib/upload/files/ arhiva $\% 20 \mathrm{GMR} / 2019 \% 20 \mathrm{gmr} /$ Conferinta\%20GMR \%202019/GMR_CONF\%20ro_Serbeszki.pdf, accesat la 14.11.2021.

9 Ibidem.

10 Norman M. Wade, "The Battle staff", SMARTbook third revised edition: Guide to designing, planning \& conducting military operations, The Lightning Press, 2019, pp. $2.29-2.40$.

11 *** FM 3-09.34 Kill Box Tactics and Multiservice Procedures, https://publicintelligence.net/fm-3-09-34-kill -box-tactics-and-multiservice-procedures, accesat la 14.11.2021.

12 Stephen P. Robbins, Organizational Theory: Structure, Design, and Applications, Prentice Hall, New Jersey, 1990, pp. 10-16. 
13 Fredrik Johansson, Göran Falkman, SWARD: System for Weapon Allocation Research \& Development, University of Skövde School of Informatics, https://www.researchgate. net/publication/224218743_SWARD_System_for_weapon_ allocation_research_development, accesat la 14.11.2021.

14 *** Join/Interagency SMARTbook: Joint strategic \& operational planing, The Lightning Press Ferlemann, 2019, pp. $13-5-13-7$.

\section{BIBLIOGRAFIE}

*** FM 3-09.34 Kill Box Tactics and Multiservice Procedures, https://publicintelligence. net/fm-3-09-34-kill-box-tactics-and-multiserviceprocedures

*** Join/Interagency SMARTbook: Joint strategic \& operational planing, The Lightning Press Ferlemann, 2019.

Iversen F. Thomas, Mobile and Netted Air Defence Systems, DK-8520 Lystrup, Denmark.

Johansson Fredrik, Falkman Göran, SWARD: System for Weapon Allocation Research \& Development, University of Skövde School of Informatics, https://www.researchgate.net/ publication/224218743_SWARD_System_for weapon_allocation_research_development

Robbins P. Stephen, Organizational Theory: Structure, Design, and Applications, Prentice Hall, New Jersey, 1990.

Roman Daniel, Riposta antiaeriană a forţelor terestre din perspectiva modelelor conceptuale de lucru colaborativ, Editura Universităţii Naţionale de Apărare „Carol I”, Bucureşti, 2017.
Şerbeszki Marius, Militarizarea Mării Negre, Conferința Gândirea militară modernă, București, 2019, https://gmr.mapn.ro/app/webroot/fileslib/ upload/files/arhiva\%20GMR/2019\%20gmr/ Conferinta\%20GMR\%202019/GMR_CONF\%20 ro_Serbeszki.pdf

Wade M. Norman, "The Battle staff", SMARTbook third revised edition: Guide to designing, planning \& conducting military operations, The Lightning Press, 2019.

https://www.defesanet.com.br/en/iaie/noticia/ 36678/IAI-s-Barak-Air-and-Missile-DefenseSystem-uses-network-centered-technology-tocreate-a-hermetic-shield/

https://defense-update.com/20210419_baraker.html

https://caspiannews.com/news-detail/armeniathreatens-azerbaijan-with-use-of-ballistic-missi les-2020-9-28-45/

https://www.middleeasteye.net/news/azerb aijan-armenia-israel-russia-missile-fired-shotdown;

https://caspiannews.com/news-detail/armeniaused-iskander-missiles-against-azerbaijan-inkarabakh-war-says-armenian-expert-2021-9-23-0/

https://www.airuniversity.af.edu/JIPA/Display /Article/2743721/the-second-nagorno-karabakhwar-takeaways-for-singapores-ground-based-airdefen/

https://www.researchgate.net/figure/A-numb er-of-OODA-loops-in-parallel-22_fig2_288970156 